DOI 10.37882/2500-3682.2020.09.05

\title{
ФИЛОСОФИЯ А.А. РОИГА КАК АРТИКУЛЯЦИЯ ЦИВИЛИЗАЦИОННОГО И КУЛЬТУРНОГО СТАНОВЛЕНИЯ ЛАТИНОАМЕРИКАНСКОГО КОЛЛЕКТИВНОГО СУБЪЕКТА ИСТОРИЧЕСКОГО ПРОЦЕССА ${ }^{1}$
}

\section{A.A. ROIG'S PHILOSOPHY AS AN ARTICULATION OF CIVILIZATIONAL AND CULTURAL FORMATION OF THE LATIN AMERICAN COLLECTIVE SUBJECT OF THE HISTORICAL PROCESS}

\section{A. Basmanov}

Summary: The Latin American philosophy of liberation was formed as an expression of the collective will of the peoples of Latin America, aimed at overcoming the totality of the Western European way of thinking and creating their own authentic philosophy. Roig A. A. is one of the most significant and prominent representatives of the philosophy of liberation. In his works, Roig explores the features of the historical process in the formation of the Latin American collective subject. The philosopher believes that the key role in shaping the specifics of the Latin American way of thinking is played by the peculiarities of the history of civilizational interaction on the continent. Roig re-evaluates the events of Latin American history, in particular, the Conquest, opening up new aspects of self-identification of Latin American ethnic groups. The main themes of his works are dependence and the need for liberation, the socio-historical dimension of philosophical discourse, the conflict of human society, the methodological expansion of philosophizing, the origin and formation of the historical subject, the decentralization of history, the correlation of theory and practice, the problem and Latin American symbolism.

Keywords: Philosophy of liberation, Latin America, collective subject of history, totality, decentralization, authentic philosophy, civilizational interaction, self-identification, ethnicity, dependence.

\section{Введение}

И нтерес к Латинской Америке особенно проявился в последние 30-40 лет. Он обусловлен многими факторами, в частности - яркой национальной спецификой латиноамериканской культуры и литературы. Особое явление культурной жизни континента представляет философия. Основной ее особенностью является резкое размежевание и противопо-
Басманов Алексей Владимирович преподаватель, Российский университет дружбы народов, Москва

basmalex1983@mail.ru

Аннотация: Латиноамериканская философия освобождения сформировалась как выражение коллективной воли народов Латинской Америки, направленной на преодоление тотальности западноевропейского образа мысли и создание своей, аутентичной философии. Роиг А.А. один из наиболее значимых и ярких представителей философии освобождения. В своих работах Роиг исследует особенности исторического процесса в формировании латиноамериканского коллективного субъекта. Философ считает, что ключевую роль в формировании специфики латиноамериканского образа мысли играют особенности истории цивилизационного взаимодействия на континенте. Роиг переоценивает события латиноамериканской истории, в частности, Конкисту, открывая новые аспекты самоидентификации латиноамериканских этносов. Основными темами его работ являются зависимость и необходимость освобождения, социально-историческое измерение философского дискурса, конфликтность человеческого общества, методологическое расширение философствования, зарождение и становление исторического субъекта, децентрализация истории, соотношение теории и практики, проблема и латиноамериканской символики.

Ключевые слова: Философия освобождения, Латинская Америка, коллективный субъект истории, тотальность, децентрализация, аутентичная философия, цивилизационное взаимодействие, самоидентификация, этнос, зависимость.

Публикация подготовлена при поддержке Программы РУДН «5-100». 
ленность на порабощение, завоевание, использование «Другого». Она показывает субъекта западной мысли возомнившим себя единственным обладателем абсолютной истины бытия и основным субъектом истории, постулировавшим только свой Логос пригодным для разговора с Богом. «Другой» приобретает статус объекта и лишается своего собственного бытия, истории, свободы и Логоса.

Именно невозможность освобождения от завоевателей в рамках европейского Логоса, полагающего бытие объекта из бытия субъекта, и посему обладающего тоталитарными интенциями в отношении «Другого», привела интеллектуальную элиту Латинской Америки к необходимости переосмыслить историю философии, роль центра и периферии в ней и проявить свою свободу посредством обоснования и актуализации самобытного способа мышления. Отличительной ее особенностью является тот факт, что народы Латинской Америки представляются философами освобождения, как коллективный субъект истории, а сами философы - представители народа, артикулирующие его стремление к свободе. В этой связи хочется отметить наличие параллели с развитием испанского национального театра в 1960-70-х гг. (Независимы театр, Мадридский свободный театр) в постфранкистской Испании, освобождающейся от гнета тоталитарного режима. «Целями Независимого театра было пропаганда народного театра, распространение сочиальной критики и поиск новой аудитории» $[1$, с.5]. Речь идет о том, что интеллектуальная и творческая элита, выражающая устремления народа, как коллективного субъекта истории, ищет пути освобождения от тотальности и артикулирует их через творчество в различных его проявлениях.

\section{Основная часть}

Объектом нашего исследования аргентинский философ Артуро Андрес Роиг (1922-2012). За свою долгую творческую жизнь он завоевал признание интеллектуальной элиты в Латинской Америке и за ее пределами наравне с Э. Дусселем. «Латиноамериканская философия представлена аргентинским философом Артуро Роигом, как философия завтрашнего дня в противовес предшествующей философской традиции; она - предвосхищение многогранного будущего, содержащегося в прошлом» $[12$, с. 151], так о нем отзываются его соотечественники. Однако в России его имя и творчество известны только в общих чертах.

Поскольку «Философия освобождения» представляет собой неоднозначное, полемичное идейное образование, в котором сосуществуют различные взгляды, тенденции и подходы, то можно смело сказать, что она все еще находится на стадии формирования. Истоки ее становления приходятся на 70-е гг. XX в., что нельзя считать серьезным сроком для превращения в зрелую систему идей. Не случайно для описания этого направления исследователями и самими представителями «философии освобождения» часто используется термин «философствование». В частности, у А. Роига почти всегда употребляет вместо существительного «философия» (filosofia) глагол «философствовать» или «мыслить» (filosofar) [5, с. 13]. Этот термин отражает процессуальный, поисковый характер философии «освобожденчской» мысли, ее постоянное развитие.

«Философия освобождения» первоначально была крайне тесно связана с «теологией освобождения» (по крайней мере до 1975 года). Позднее идея междисциплинарного развития философии потребовала пересмотра роли теологии внутри философского контекста и разработки новых, интегративных категорий [9, с. 80]. «Теология освобождения» оказала сильное влияние на творчество многих латиноамериканских философов, однако многие из них предпочли иной путь поиска аутентичной философии. В «философии освобождения» различают два основных направления [2, с. 243-249].

Первое во многом сформировалось под влиянием «теологии освобождения», его представляют Э. Дуссель, Х. Ассманн, Х.К. Сканнонне, М. Касалья, Р. Куш и др. В целом их позицию отличает сосредоточенность на критической задаче деструкции учений западной философии как идеологической основы «господства» с целью очищения пространства для нового сознания, а также особое внимание к онтологическим, методологическим, этическим вопросам. Творчество некоторых представителей этого направления (напр., Х.К. Сканнонне, М. Касалья и Р. Куш) может быть так же рассмотрено как «инкультурная философия», т.е. философия, «укорененная» в конкретную культуру, опирающуюся на нее в своих теоретических изысканиях [3, с. 127].

Деятельность представителей второго направления «философии освобождения» (А. Роиг, Г. Серутти, М. Сантос и др.) в большей степени связана с историей идей на континенте. Они стремятся воссоздать картину философского процесса в Латинской Америке и в этом опыте ищут основу для построения аутентичной философии. Наряду с философской проблематикой представители данного направления работают так же с проблемами эпистемологии, политики, идеологии. Их интересует разработка вопроса политической роли философии как специфической практики. В рамках этого направления философствования прежней философии как «теории свободы» противопоставляется новая философия, понимаемая как «освобождение». Здесь утверждается приоритет объекта перед субъектом, решающая роль практики по отношению к теории. Эта линия «философии освобождения» исходит из присущего угнетенным «сознания инаковости» как мобилизующего начала в 
освободительной борьбе. Если представители первого направления в идейном плане тяготеют к популизму, то представители второго - напротив, критикуют его.

А. Роиг по своим взглядам безусловно принадлежит ко второму направлению. Основными темами его работ являются зависимость и необходимость освобождения, социально-историческое измерение философского дискурса, конфликтность человеческого общества, методологическое расширение философствования, зарождение и становление исторического субъекта, децентрализация истории, соотношение теории и практики, проблема интерпретации лингвистических знаков и латиноамериканской символики. Эти проблемы показывают, что А. Роиг представляет ту линию «философии освобождения», которая ориентирована на историцизм $[2$, c. 250].

Тема кризиса западноевропейской «философии субъекта», в которой сущность имела приоритет над существованием, субъект над объектом, также проходит красной нитью через многие работы Роига. На критике идеалистической философии Гегеля вырастает новый тип философии, который исходит из первичности объекта по отношению к субъекту. Начало этой философии Роиг увязывает с фигурой Маркса (а также видит ее элементы у Ницше и Фрейда) и называет ее «философией объекта», поскольку она дает возможность говорить о зависимости субъекта от его конкретных исторических условий, о становлении и зарождении субъекта в истории $[12$, с. 153].

В работах, посвященных анализу взглядов Роига отмечается, что его мышление имеет много различных форм выражения, которые в целом можно обозначить как «эмпирический историцизм» (el historicismo empírico) [lbidem]. Такая характеристика творчеству Роига дается не случайно. Как и многие другие интеллектуалы, представляющие «философию освобождения», Роиг значительное внимание уделяет проблеме исторического процесса как основе формирования сознания субъекта. Именно в истории формируется коллективное «Мы» латиноамериканских народов, являющееся ее субъектом. Исторический процесс, позволяющий человеку обрести свою идентичность, носит для Роига эмпирический характер, т. к. это реальное пространственно-временное движение исторического бытия. Обнаружение себя в пространстве и времени дает возможность человеку обнаружить себя и в качестве субъекта исторического процесса.

Вопрос о роли метафизики в «философии освобождения» также является предметом внимания философов «освобождения». Роиг считает, что в качестве основания теории метафизику следует избегать, т. к. она «неприемлема в силу отсутствия в ней ясности, что затрудняет концептуальный анализ и теоретическое обоснование проекта освобождения» [3, с. 84]. Однако позиция Роига по вопросам роли метафизики в «философии освобождения» шире и не сводится к простому отрицанию: важным моментом его концепции «антропологического априори», изложенной в работе «Теория и критика латиноамериканского образа мысли» [6], является указание на то, что разум, достигший этапа спекулятивного мышления, имеет неизбежную склонность к метафизике.

Роиг в той или иной степени разделяет характерное для всей «философии освобождения» критическое отношение к «разуму». Для завоевателей «разум» является тем, что повелевает и иерархизирует, поэтому для угнетенного он является не-разумом. Для философии угнетателей любое изменение теоретически представлено как имманентное «разуму», тогда как сознание угнетенного всегда исходит из подсознательного желания изменения, прорыва этого оправдывающего действия угнетателя и повелевающего разума. Представляется, что это подсознательное желание проявляется в стихийно возникающем массовом сознании протеста, который в свою очередь является источником «философии освобождения». Этот подсознательный протест также порождает то, что было названо деятелями «философии освобождения» «сознанием инаковости». Имеется в виду осознание угнетенным своего социального отличия от угнетателей, противостояние господствующей системе в качестве «Другого» и понимание необходимости радикальных перемен и становления иного общества. Однако позицию Роига отличает двоякое отношение к «разуму». В своих работах ("Rostro у filosofía de América Latina" [7] и "El pensamiento latinoamericano y su aventura" [8]) Роиг «показывает ограниченность классического рационализма и необходимость более широкого понимания разума» [4, с. 99]. Дело в том, что для Роига рациональное остается базовой компонентой духовной деятельности человека. Критике же философ подвергает ту форму разума, в которой он предстал в философии модерна. Т. е. он негативно относится к таким свойствам разума в его западноевропейской трактовке как тотальность, универсализм, эгоцентризм. Кроме того, критике с его стороны подвергается европоцентристская интерпретация историко-философского процесса, ставшая результатом воплощения в жизнь вышеуказанных свойств разума философии модерна.

По целям своих философских поисков Роиг не отличается от «коллег по цеху». Он ищет базис для построения аутентичной философии, созданной от имени латиноамериканского коллективного субъекта истории, сознание которого сформировалось в особых исторических условиях Латинской Америки. Основу этого сознания Роиг ищет в языке, в истории латиноамериканских народов, которая представляет собой «антропологическое априори» современного латиноамериканского со- 
знания. Основной задачей «философии освобождения» Роиг считает разработку новых интегрирующих понятий, которые исходили бы из историчности человека. Необходимо выработать теорию, которая дала бы адекватные концептуальные инструменты, позволяющие каждому человеку всецело включиться в дело народного освобождения. Историчность обыкновенного человека раскрывается в его повседневном опыте, а не в мыслях философа. Она раскрывается в действиях человека как творца и преобразователя своего мира [12, с. 154].

Конкиста как историческое событие вызывает особый интерес у философов «освобождения», поскольку оно в корне изменило жизнь латиноамериканских народов. Именно с осмысления значения этого события для жизни Латинской Америки начинается любое философское осмысление современной латиноамериканской действительности.

Конкиста была моментом столкновения двух субъектов: европейского и латиноамериканского. Этот момент обозначается как «надлом» (ruptura). Переосмыслению его значения Роиг уделяет особое внимание в своей работе «Открытие Америки и встреча культур» [10], написанной к 500-летию открытия Америки и прочитанной Роигом на пятом Национальном Философском Конгрессе в Венесуэле (Congreso Nacional de Filosofía de la Sociedad Venezolana de Filosofía, 1991). В этой работе он стремиться показать неадекватность европейской интерпретации различных понятий, связанных с Конкистой.

Роиг развивает идеи Л. Сеа о том, что «Открытие Америки было скорее ее «Закрытием», т.к. благодаря этому «Открытию» были разрушены великие культуры [10]. Роиг обвиняет европейских историков в искажении реального смысла процесса посредством введения термина «встреча двух культур» (encuentro de dos culturas). По его мнению, это была «рас-встреча двух культур» (desencuentro de dos culturas).

Европейская интерпретация во многом скрадывает реальную окраску завоевания Америки, т.к. понятие «Открытия» отделяется от понятия «Конкиста», «наполненного военной агрессией и коварством» [10]. На самом же деле эти два процесса протекали единовременно и отделены друг от друга быть не могут. Совмещенное понятие «открытие-конкиста» должно говорить об отношении между посланником и приемником (entre un emisor y un receptor), «оба они находятся на одном уровне (en pie de igualdad) и говорят на одном языке - языке доминирования в мире. Их культурное взаимодействие нельзя охарактеризовать как послание спасения ("mensaje de salvación") одной культуры другой, это межкультурное послание» [10]. Не было добрых испанцев, пришедших, чтобы осчастливить своей культурой, и не было латиноамериканцев, готовых с радостью принять ее. Была борь- ба двух сторон. Эта борьба должна была определить, кто будет править, а кто - подчиняться. И в этом смысле обе стороны были в одинаковых условиях. Захватническое поведение европейцев, вылившееся в конкисту, можно понять, т.к. «любая нация, цивилизующая другую, обычно считает, что говорит на самом прекрасном языке в мире, что ее культура - наиболее развитая и что она обладает цивилизаторским потенциалом» [10].

500-летие «Открытия» Латинской Америки ставило перед ее народами вопрос: как относиться к этому юбилею - праздновать его или нет? На этот вопрос Роиг однозначно отвечает «нет», т.к. для латиноамериканцев это «празднование эксплуатации и смерти своих прародителей» [10]. Можно утверждать, что Латинская Америка только выиграла от Конкисты. Однако «если население Америки и выиграло в плане получения технологических достижений Запада, то это было население, образовавшееся в результате метизации, но какова была цена для народов, которые непосредственно встретились с испанцами» [10].

Так же в этой работе Роиг дает оценку «культурным благам» (los bienes culturales), принесенным на континент европейцами. «Культурные блага сами по себе ничего не стоят, - пишет он, - они - всего лишь моменты истории, ... они ценны настолько, насколько мы признаем их ценность, принимая их как часть нашей истории и оставаясь при этом свободными» [10]. Такая формулировка четко отражает позицию «философии освобождения» по поводу взаимоотношений различных культур. А именно, культурные блага при переходе от одной культуры к другой остаются благами только тогда, когда этот переход осуществляется без насилия, когда одна культура добровольно принимает другую.

Однако Роиг все же признает ценность культурных благ, принесенных в Латинскую Америку европейцами. Ценность эта, в первую очередь, состоит в том, что латиноамериканские народы имеют единое культурное «наследие» (legado). Имеются в виду «унаследованные блага, которые составляют то, что можно назвать духовной культурой; среди этих благ выделяются по силе и «частоте использования» религия, в основном как культурная практика, язык, обычаи, понятие «раса», «земля», каждое из них имеет соответствующую идеологическую окраску, призванную формировать континентальную идеологию» [6]. Именно общее «наследие» латиноамериканских народов позволяет говорить о коллективном субъекте истории.

Историческая ценность прошлого, т.е. «ОткрытияКонкисты», состоит в том, что знание о нем обогащает историческую память и развивает критическую мысль. Роиг настаивает на том, что нельзя не ценить или игнорировать это прошлое, т.к. оно сыграло свою положи- 
тельную роль в достижении латиноамериканцами определенного уровня самосознания и в становлении их как субъекта истории. Борьба за свободу сплотила народы Латинской Америки и развила их самосознание, а интеллектуальное противостояние с чуждого духу латиноамериканца европейским Логосом только укрепило позиции национальной философии.

\section{ЗакАючение}

Роль социально-исторического процесса в формировании латиноамериканского коллективного исторического субъекта красной нитью проходит через многие работы Роига. Очевидно, что латиноамериканский субъект истории уже сформировался, т.к. если бы дела обстояли иначе, то не было бы столь усиленной рефлексии над латиноамериканской реальностью в виде философии освобождения. Субъект формируется историческими условиями. К познанию этих условий и призывает Роиг в своем творчестве, ибо знание, правильное понимание и интерпретация своей истории создает соответствующую самоидентификацию. Это путь становления латиноамериканских этносов, как самостоятельного коллективного субъекта историко-культурного и цивилизационного процесса.

\section{ЛИТЕРАТУРА}

1. Басманова А.А., Галаева Е.И. Хосе Луис Алонсо де Сантос в театральной жизни своего времени // Культура и цивилизация. 2020. Том 10. № 1 А. С. 5-11. DOI: 10.34670/AR.2020.47.1.001

2. Деменчонок Э.В. Философия «освобождения». // Из истории философии Латинской Америки XX века. М.: Наука, 1988. С. 236-266

3. Петякшева Н.И. Латиноамериканская «философия освобождения» в контексте компаративистики. М.: «Уникум-центр», 2000. - 232 с.

4. Demenchonok E. Book reviewing (Roig A.A. Rostro y filosofía de América Latina. Mendoza: Editorial de la Universidad Nacional de Cuyo (EDUNC). 1993.; Roig A.A. El pensamiento latinoamericano y su aventura. 2 tomos. Buenos Aires: (entro Editor de América Latina, 1994.)//Concordia, Pontificia Universidad Javeriana, Bogotá, Colombia, 1995, №28. P. 97-101.

5. Marquez-Fernandez, Alvaro B. Roig A.A.: un filosofar en America Latina//Horizontes filosoficos: revista de filosofia, Humanidades y Ciencias sociales, [S.I.], n.3, p.13-30, may 2014. ISSN 2250-5180 [Электронный ресурс]. URL: http://revele.uncoma.edu.ar/htdoc/revele/index.php/horizontes/article/view/176/171. (дата обращения: 02.08 .2020$)$.

6. Roig, Arturo Andrés. Teoría y crítica del pensamiento latinoamericano, México: FCE, 1981. 315 р. [Электронный ресурс]. URL: https://www.ensayistas.org/ filosofos/argentina/roig/teoria/indice.htm (дата обращения: 02.08.2020).

7. Roig, A.A. Rostro y filosofía de América Latina. Mendoza: EDIUNC, $1993.230 \mathrm{p}$

8. Roig, A.A. El Pensamiento latinoamericano y su aventura. Ed. corregida y aumentada. El andariego, Buenos Aires, 2008. 283 pp

9. Roig A.A. Mis tomas de possicion en filosofia. // Concordia, Pontificia Universidad Javeriana, Bogotá, Colombia, 1993, №23. P.76-91.

10. Roig A.A. Descubrimiento de América y encuentro de culturas. (1991) [Электронный ресурc]. URL: https://www.ensayistas.org/antologia/XXA/roig/culturas.htm (дата обращения: 25.07.2020).

11. Roig A.A. Ética del poder y moralidad de la protesta: La moral latinoamericana de la emergencia. [Электронный ресурc]. URL: https://www.ensayistas.org/ filosofos/argentina/roig/etica/etica22.htm (дата обращения: 12.07.2020).

12. Vignale, Silvana P. Arturo A. Roig: la filosofía latinoamericana como filosofía auroral. Utopia y Praxis Latinoamericana, Maracaibo, v.15, n.51, p. 151-158, Dec. 2010. ISSN 1315-5216. [Электронный ресурc]. URL: http://ve.scielo.org/scielo.php?script=sci_arttext\&pid=S1315-52162010000400011\&lng=en\&nrm=iso. (дата обращения: 20.07.2020).

13. Zavala C.P. A.A. Roig. La filosofía Latinoamericana como compromiso. 1998 [Электронный pecypc]. URL: https://www.ensayistas.org/filosofos/argentina/roig/ introd.htm (дата обращения: 01.08.2020).

(с) Басманов Алексей Владимирович (basmalex1983@mail.ru). Журнал «Современная наука: актуальные проблемы теории и практики» 